\title{
Yields and quality of biomasses and grain in Cynara cardunculus L. grown in southern Italy, as affected by genotype and environmental conditions
}

\author{
Lucia Ottaiano, ${ }^{1}$ Ida Di Mola, ${ }^{1}$ Adriana Impagliazzo, ${ }^{1}$ Eugenio Cozzolino, ${ }^{2}$ Felicia Masucci, ${ }^{1}$ \\ Mauro Mori, ${ }^{1}$ Massimo Fagnano ${ }^{1}$ \\ ${ }^{1}$ Department of Agricultural Sciences, University of Naples Federico II, Portici (NA); ${ }^{2}$ Council for \\ Agricultural Research and Economics, Research Center for Cereals and Industrial Crops, Caserta, Italy
}

\begin{abstract}
Cardoon is a crop well adapted to Mediterranean climatic conditions that is able to grow also in marginal lands thus reducing competition for land with food crops. It is considered a key crop for bio-refinery since it allows producing different interesting molecules for industrial application. From stems it is possible to obtain large amounts of cellulose, grains are a good source of oil and proteins and roots can be a source of inulin. The aim of this research has been to evaluate the productive levels of different genotypes of cardoon in two different climatic conditions of Mediterranean cropland (a site in the Vesuvius plain and a site in the internal hilly cropland). In both the sites, during 3 years (from 2012-2013 to 2014-2015), three genotypes (Altilis, Gigante e Trinaseed) were cultivated with 2 planting densities (4 and 8 plants per $\mathrm{m}^{2}$ ). A low input cropping system was adopted (no irrigation and $150 \mathrm{~kg} \mathrm{ha}^{-1}$ of $\mathrm{N}$ supplied as ammonium nitrate). In flat site (NA-Ac.), lignocellulosic biomass yield was $19 \mathrm{t} \mathrm{ha}^{-1}$ d.m. and grain yield $2.7 \mathrm{t} \mathrm{ha}^{-1}$ on the average of the 3 years period. In
\end{abstract}

Correspondence: Lucia Ottaiano, Department of Agricultural Sciences, University of Naples Federico II, via Università 100, 80055 Portici (NA), Italy.

E-mail: lucia.ottaiano@unina.it

Key words: Biomass yield; Biomass and grain composition; Cardoon; Grain yield.

Acknowledgements: this work has been financed by the project MIUR PON01_1966 EnerbioChem (Integrated agro-industrial chains with high energy efficiency for the development of eco-compatible processes of energy and biochemicals production from renewable sources and for the land valorisation).

Received for publication: 7 March 2017.

Revision received: 30 May 2017.

Accepted for publication: 10 June 2017.

CC Copyright L. Ottaiano et al., 2017

Licensee PAGEPress, Italy

Italian Journal of Agronomy 2017; 12:954

doi:10.4081/ija.2017.954

This article is distributed under the terms of the Creative Commons Attribution Noncommercial License (by-nc 4.0) which permits any noncommercial use, distribution, and reproduction in any medium, provided the original author(s) and source are credited. the hilly site, biomass yield was similar $\left(20 \mathrm{t} \mathrm{ha}^{-1}\right.$ d.m. $)$ while grain yield was higher (3.9 $\mathrm{t} \mathrm{ha}^{-1}$ on the average) as compared to the flat site. As regards biomass composition, an increase of hemicellulose and a decrease of cellulose content were measured in the flat site, maybe as a response of plant to the higher drought stress.

\section{Introduction}

Cardoon (Cynara cardunculus L.) is a perennial species with origin in the Mediterranean basin (Gatto et al., 2013; Raccuia et al., 2004a). The interest in the cultivation of this crop is growing in European Countries such as Spain, France and Italy, because it is particularly adapted to low rainfalls and very warm conditions during summer period (Raccuia et al., 2004).

In recent years, cardoon has been considered as a key crop in biorefineries because it is able to produce a series of molecules interesting for industrial applications. Its adaptability to climatic limitations of Mediterranean areas also allows its cultivation in marginal lands, thus reducing competition for land between food and non-food crops (Fagnano et al., 2015).

The lignocellulosic (LC) biomass of stems can be used as solid biofuel for renewable energy production by combustion, pyrolysis and gasification (Gonzales et al., 2004a, 2004b; Ochoa and Fandos, 2004). The theoretical caloric value is from 16,500 to $17,028 \mathrm{~kJ} \mathrm{~kg}^{-1}$ of dry matter (Piscioneri et al., 2000; Encinar et al., 2002a, 2000b). It can also be uses for paper pulp (Antunes et al., 2002; Gominho et al., 2001) or pellet for domestic heating (Gonzalez et al., 2004a; Toscano et al., 2016) or raw material for bioethanol production or co-digestion for methane production (Kalamaras et al., 2014).

Cynara is botanically related to the sunflower and like sunflower it produces oil fruits, which are usually known as seeds. The parameters that show the potential of cynara as an oil crop are: seed yield, seed oil content, fatty acid profile and heating value. The seed yield of cynara crop has been estimated at $1.36 \mathrm{t}$ ha $^{-1}$ year $^{-1}$ in Central Spain (Fernandez and Curt, 2004). Seed oil content and fatty acid profile have been studied by Maccarone et al. (1999) and Curt et al. (2002). A maximum seed oil content of $32.47 \%$ has been reported (Curt et al., 2002). The oil composition is similar to common sunflower oil: $11 \%$ palmitic, $4 \%$ stearic, $25 \%$ oleic and $60 \%$ linoleic fatty acids, on average.

Cynara seed oil can be easily extracted by cold pressing $\left(20 / 25^{\circ} \mathrm{C}\right)$; in this way, the oil composition is not altered and the product can be used for food applications. However, the oil from cynara is also recommended for energy purposes. So, if the LC biomass is used as a solid biofuel and the seeds for oil production, 
the crop costs can be shared between these two products; in this way the oil cost would be lower than the cost of sunflower oil (Fernandez and Curt, 2004).

Also oleaginous grains can be used for different purposes. Cardoon oil can be used for human consumption, since it is characterised by optimal linoleic/oleic ratio (about 1:8), absence of erucic acid and high levels of alfa-tocopherol, which offers stability against oxidation (Maccarone et al., 1999). Oil can also be used for biodiesel production (Encinar et al., 1999; Ma and Hanna, 1999) or for biopolymer production (Fagnano et al., 2015).

Due to high protein content, the residual flour after oil extraction from grain can be used for animal feed (Fernández and Manzanares, 1990; Foti et al., 1999). Fresh biomass is suitable to be used as winter forage for livestock feeding (Cravero et al., 2012).

Furthermore, from the roots it is possible to extract inuline (Raccuia and Melilli, 2004, 2010) that is very interesting for functional foods for diabetics (it reduces the absorption of glucose) or celiacs (it can substitute gluten thanks to its rheological properties (Sillitti et al., 2016) Agronomic experiments aimed to analyse the behaviour of the new genotypes of this species or of different plant density (Raccuia et al., 2011) in different Mediterranean cropping systems are scarce and very recent.

Therefore the aims of this work were: i) to evaluate yield potential of three genotypes in two contrasting environmental conditions; ii) to compare different plant densities; iii) to evaluate the quality of the LC biomass and grain.

\section{Materials and methods}

\section{Experiment set-up and crop management}

The objective of this study was to evaluate the interaction Cultivars by Locations and the influence of grain density on biomass and grain production of cardoon (Cynara cardunculus). In particular, the experiments were made in two contrasting environments: Sant'Angelo dei Lombardi, Avellino (AV), a hilly area subjected to soil erosion (700 $\mathrm{m}$ a.s.1.) and characterized by cold and rainy winters and low-fertility soils (Fagnano et al., 2015) and Acerra, Naples (NA), a flat area (28 m a.s.1.) characterised by dry and very warm spring-summers and by very fertile soils (Fiorentino et al., 2013).

Three genotypes (Altilis, Gigante and the new cultivar Trinaseed) were compared during 3 seasons (from 2012-2013 to 2014-2015), with two-plant density: $4(0.75 \times 0.33 \mathrm{~m})$ and $8(0.75$ x $0.17 \mathrm{~m}$ ) plants per $\mathrm{m}^{2}$.

Low input crop management was applied every year (no irrigation and $150 \mathrm{~kg} \mathrm{ha}^{-1}$ of $\mathrm{N}$ supplied as ammonium nitrate); only a supplemental watering was made after transplanting for support the establishment of the crop.

Seedlings at the stage of three-four leaves were transplanted in open field on May 2012. The harvests were made on: September 5, 2013, September 1, 2014, and September 10, 2015 in AV and on

At harvest, plant height, number of plants per $\mathrm{m}^{2}$ and number of heads per plant were measured.

The plants were cut at ground level and separated in stems and heads. Heads were then threshed with a specific mini-thresher for separating grains. August 12, 2013, August 1 2014, and August 4, 2015 in NA.

\section{Chemical analyses}

In laboratory, moisture content of biomass components (stalks, leaves, heads and grains) was measured by weighing $150 \mathrm{~g}$ of the different biomasses and drying them in oven a $50{ }^{\circ} \mathrm{C}$ until constant weight.

In the last year, dry samples were then used for analysing their chemical composition: Neutral-detergent fibre (NDF), Acid-detergent fibre (ADF) and Acid-detergent lignin (ADL) were determined using an Ankom 200 Fibre Analyser, following sequential extractions in hot neutral- detergent solution $\left(100^{\circ} \mathrm{C}\right.$ for $\left.1 \mathrm{~h}\right)$, hot acid-detergent solution $\left(100^{\circ} \mathrm{C}\right.$ for $\left.1 \mathrm{~h}\right)$ and incubation in $72 \%$ $\mathrm{H}_{2} \mathrm{SO}_{4}(3 \mathrm{~h})$ (Goering and Van Soest, 1970). The content in lignin was considered corresponding to ADL, the content of cellulose was calculated as ADF-ADL, the content in hemi-cellulose was calculated as NDF-ADF.

Nitrogen content of biomass and grains was also measured by the Kjeldahl method. Oil was extracted from grains through cold pressing. During the experimental period, soil samples of two layers $(0-20,20-40 \mathrm{~cm})$ were collected from each plot in the same dates of biomass samplings, for measuring organic $\mathrm{N}$ and $\mathrm{C}$ by the Kjeldahl and Walkley-Black methods, respectively. Concentrations of $\mathrm{NH}_{4}{ }^{-}-\mathrm{N}$ and $\mathrm{NO}_{3}{ }^{-}-\mathrm{N}$ were measured according to the $\mathrm{Hach}^{\circledR}$ method, and the extracts were analysed by spectrophotometry (Hach DR 2000, Hach Company, Loveland, CO, USA).

\section{Statistical analysis}

All data were subjected to analysis of variance by using the software MSTAT- C (Crop and Soil Science Department, Michigan State University). Two Factor Randomized Complete Block Design with Split Plot Combined over Locations and Years was used.

As regards biomass composition, which was measured only in the last year, the design Two Factor Randomized Complete Block Design with Split Plot Combined over Locations was used.

In main plots three cultivars were randomized in three blocks, two seed densities were randomized in sub-plots. All means were separated by using the LSD test at the 0.05 probability level.

\section{Characteristics of study sites}

The site of Sant'Angelo dei Lombardi (AV) has a clay-loam (USDA), sub-alkaline soil with a low content of $\mathrm{N}$ and organic matter (Table 1). At sowing, the $\mathrm{NO}_{3}-\mathrm{N} / \mathrm{NH}_{4}-\mathrm{N}$ ratio is 1.25 , thus

Table 1. Physical and chemical soil properties in the two sites (0$20 \mathrm{~cm})$.

\begin{tabular}{lcc} 
& S. Angelo (AV) & Acerra (NA) \\
Clay (\%) & 38.5 & 14.4 \\
Silt (\%) & 25.0 & 22.6 \\
\hline Sand (\%) & 36.5 & 63.0 \\
$\mathrm{pH}$ & 8.1 & 7.3 \\
\hline $\mathrm{N}^{-N_{3}}(\mathrm{ppm})$ & 20 & 26 \\
$\mathrm{~N}^{-N H_{4}}(\mathrm{ppm})$ & 16 & 17 \\
\hline $\mathrm{OM}(\%)$ & 1.3 & 2.6 \\
$\mathrm{OC}(\%)$ & 0.8 & 1.5 \\
\hline C/N & 8.0 & 9.0 \\
Total N (\%) & 0.1 & 0.2
\end{tabular}


indicating moderate oxygen availability in the soil, and consequently a moderate aptitude to nitrification (Fiorentino et al., 2016).

The site of Acerra (NA), has a sandy loam, neutral soil, with a good contend of $\mathrm{N}$ and organic matter (Table 1). Initial $\mathrm{NO}_{3}$ $\mathrm{N} / \mathrm{NH}_{4}-\mathrm{N}$ ratio is 1.53 , thus indicating higher oxygen availability in the soil, and consequently a higher aptitude to nitrification.

\section{Agro-meteorological conditions}

During the 3 years of the experiment, temperature and rainfall were measured by meteorological stations. Reference evapotranspiration was calculated by Hargreaves and Samani (1985) method.

The hilly site (AV) is characterised by very low minimum temperatures in winter $\left(-3\right.$ to $\left.1.5^{\circ} \mathrm{C}\right)$. Summer temperatures reached $32^{\circ} \mathrm{C}$. The mean annual amounts of rainfall were $1200,890,983$ $\mathrm{mm}$ in the three years, respectively (Figure 1). Summer (MayAugust) water deficits (Rainfall - $\mathrm{ET}_{0}$ ) were 524, 580,781 respectively in 2013, 2014 and 2015.

The flat site (NA) (Figure 2) was mainly characterised by air temperatures increasing from April to August with minimum monthly values ranging from 5 (Dec.-Mar.) to $19^{\circ} \mathrm{C}$ (Jun.-Sep.) and maximum values ranging from 16 (Dec.-Mar.) to $32^{\circ} \mathrm{C}$ (Jun.-Sep.).

The mean annual amount of rainfall observed in 2013, 2014 and 2015 were 852, 1243, $653 \mathrm{~mm}$, respectively. Summer (MayAugust) water deficits (Rainfall - $\mathrm{ET}_{0}$ ) were 530, 683,689 respectively in 2013, 2014 and 2015.

In June 2014 there was a violent windstorm event with about $30 \mathrm{~mm}$ of rain in 1 hour and wind gusts exceeding $100 \mathrm{~km} \mathrm{~h}^{-1}$.

As expected, the hilly site (S.Angelo-AV) was less warm $(-10 \%$ in average temperatures) and more rainy $(+12 \%$ in average annual rainfalls), thus indicating lower drought conditions, as compared with plain site (Acerra-NA).

\section{Results and discussion}

\section{Biomass and grain yield}

Results of the analysis of variance (Table 2) did not show significant differences for most parameters.

Only two interactions were significant: the interaction Years $\mathrm{x}$ Locations for all parameters and the interaction Localitions $\times$ Cultivars only for seed yield.

As regards main factors, from Table 3 it is possible to notice a decreasing trend from $1^{\text {st }}$ to $3^{\text {rd }}$ year for all the parameters. The average yield of the 3 year cropping period was $3.3 \mathrm{t} \mathrm{ha}^{-1}$ of grains and $13.0 \mathrm{tha}^{-1}$ of $\mathrm{LC}$ residues.

Also Gherbin et al. (2001) reported a decreasing cardoon yield from the first to the last season $\left(5^{\text {th }}\right.$ in that case) for all the 17 cultivars cultivated under Mediterranean climate. In that work, the Authors found that yield of the different cardoon cultivars had a very large variability, ranging between 5 and $14 \mathrm{t} \mathrm{ha}^{-1}$ year-1 in environmental conditions characterized by mean annual rainfall of $500 \mathrm{~mm}$.

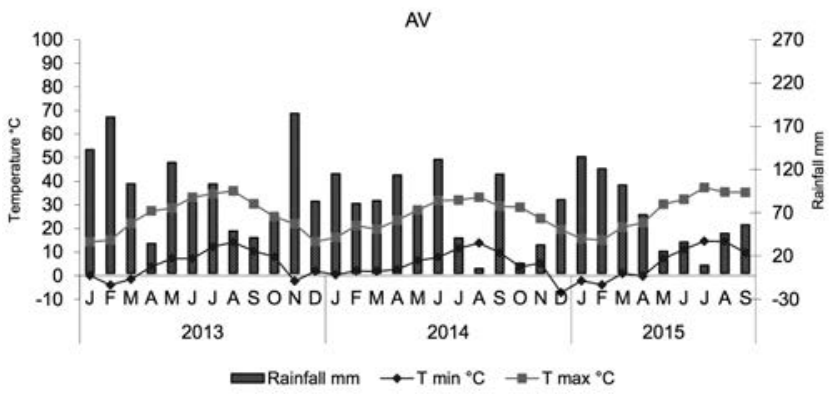

Figure 1. Agro-meteorological parameters of the different years (2013-2014-2015) in hilly site. Values with different letters indicate significant differences per $\mathbf{P} \leq \mathbf{0 . 0 5}$.

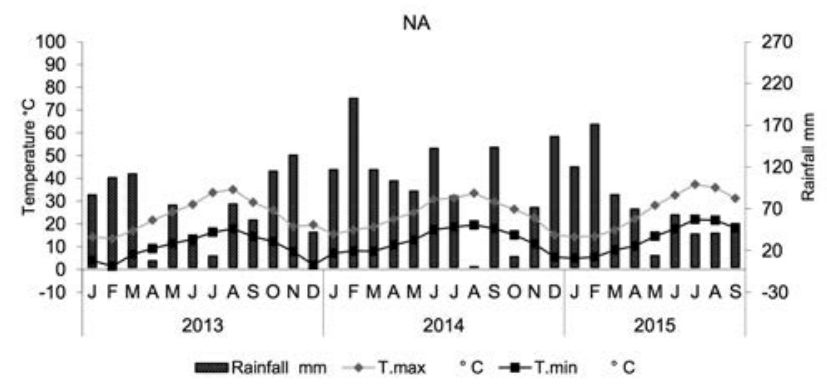

Figure 2. Agro-meteorological parameters of the different years (2013-2014-2015) in flat site.

Table 2. Analysis of variance of yields parameters: significance of main factors and interactions.

\begin{tabular}{|c|c|c|c|c|c|c|c|}
\hline & $\begin{array}{l}\text { Plant density } \\
\text { (num. } / \mathrm{m}^{2} \text { ) }\end{array}$ & $\begin{array}{l}\text { Total biomass } \\
\text { (t ha-1 d.m.) }\end{array}$ & $\begin{array}{c}\text { Crop residues } \\
\text { (t ha- } \mathbf{h}^{-1} \text { d.m.) }\end{array}$ & $\begin{array}{c}\text { Grains } \\
\text { (t ha- d.m.) }\end{array}$ & $\begin{array}{l}\text { HI } \\
(\%)\end{array}$ & $\stackrel{\mathrm{N}}{\text { content }(\%)}$ & $\begin{array}{c}\mathrm{N} \\
\text { uptake }\left(\mathrm{kg} \mathrm{ha}^{-1}\right)\end{array}$ \\
\hline Year & 0.01 & 0.01 & 0.01 & 0.01 & 0.01 & & \\
\hline Location & 0.01 & & & 0.01 & 0.01 & & 0.01 \\
\hline $\mathrm{Y} \times \mathrm{L}$ & 0.01 & 0.01 & 0.01 & 0.01 & 0.01 & & 0.01 \\
\hline Cultivar & & & & & 0.05 & & \\
\hline \multicolumn{8}{|l|}{$\mathrm{Y} \times \mathrm{C}$} \\
\hline $\mathrm{L} \times \mathrm{C}$ & & & & 0.05 & & & 0.05 \\
\hline Density & 0.01 & & & & & & \\
\hline $\mathrm{CV}$ & $16.8 \%$ & $27.7 \%$ & $34.2 \%$ & $34.3 \%$ & & & $25.2 \%$ \\
\hline
\end{tabular}

$\mathrm{HI}$, harvest index; $\mathrm{N}$, nitrogen; $\mathrm{CV}$, cultivar. 
On the contrary, yield resulted increasing or stable in the first years of other experiment in very different environment: Raccuia and Melilli (2007) reported increasing values of total biomass from $1^{\text {st }}$ to $3^{\text {rd }}$ year (from 7.5 to $20.2 \mathrm{t} \mathrm{ha}^{-1}$ ). In that study a supplemental irrigation with $50 \mathrm{~mm}$ (at flowering on May) was applied. Ierna et al. (2012) reported almost constant yield levels (total biomass was 15.4, 21.9 and $22.9 \mathrm{t} \mathrm{ha}^{-1}$ in the first three years respectively) in experiments made in Southern Italy.

The average values were higher in AV as compared to NA mainly as regards grain yield (4.0 vs $\left.2.6 \mathrm{t} \mathrm{ha}^{-1}\right)$ suggesting higher plant fertility in hilly site, confirmed by the higher harvest index (HI) $(20 \%$ vs $14 \%$ in hilly and plain site, respectively). The Trinaseed cultivar confirms the higher HI $(18.3 \%)$ than the other two genotypes, with a mean yield of $3.5 \mathrm{t} \mathrm{ha}^{-1} \mathrm{~d} . \mathrm{m}$.

Lower yield values were reported by Curt et al. (2002) and Fernández et al. (2005) with average values of different Mediterranean not irrigated sites of $1.3 \mathrm{t} \mathrm{ha}^{-1}$ of grain yield and 14 $\mathrm{t} \mathrm{ha}^{-1}$ of biomass yield.

Values of the three cultivars were not different on the average, but the significant interaction Locations $\times$ Cultivars for grain yield could suggest a different attitude to produce grains of the three genotypes in the different environmental conditions (Figure 3).

The cultivars Trinaseed and Gigante showed higher grain productivity in the hilly site (AV-S.An), while Altilis showed a more stable grain yield without significant difference between hilly and plain sites.

The effect of seed density was significant only for plant density at harvest, but values were lower that those planned at sowing, suggesting that a high mortality rate of plants could represent a strategy of self-regulation of plant population, aimed to reduce intra-crop competition.

The interaction Years $\times$ Locations, that was significant for all the measured parameters, is related to the different meteorological conditions in the two sites, as also reported by Raccuia et al. (2011).

The number of plant per $\mathrm{m}^{2}$ decreased from $1^{\text {st }}$ to $3^{\text {rd }}$ year in both the sites (Figure 4A), although with a different trend between the two locations.

In the plain site (NA-Ac.) total biomass (Figure 4B), LC residues (Figure 4C) and grain yield (Figure 4D) were very low in the $2^{\text {nd }}$ year because of the injuries caused by the violent storm event on June 14, 2014. In the $3^{\text {rd }}$ year plant growth recovered and biomass and grain yields were higher and similar to the ones of the $1^{\text {st }}$ year.

In hilly site, biomass and grain yield (Figure 4C and D) were higher in the first two years and decreased in the $3^{\text {rd }}$ year, mainly for a stunted plant development (total biomass per plant was only $266 \mathrm{~g}$ d.m. per plant, data not shown). This was due to a more severe water deficit than the two previous years (781 vs 524 and $580 \mathrm{~mm}$ in the first 2 years). Similar results were reported also by Fernandez et al. (2006) that related yield variability to different water availability due to rain distribution.

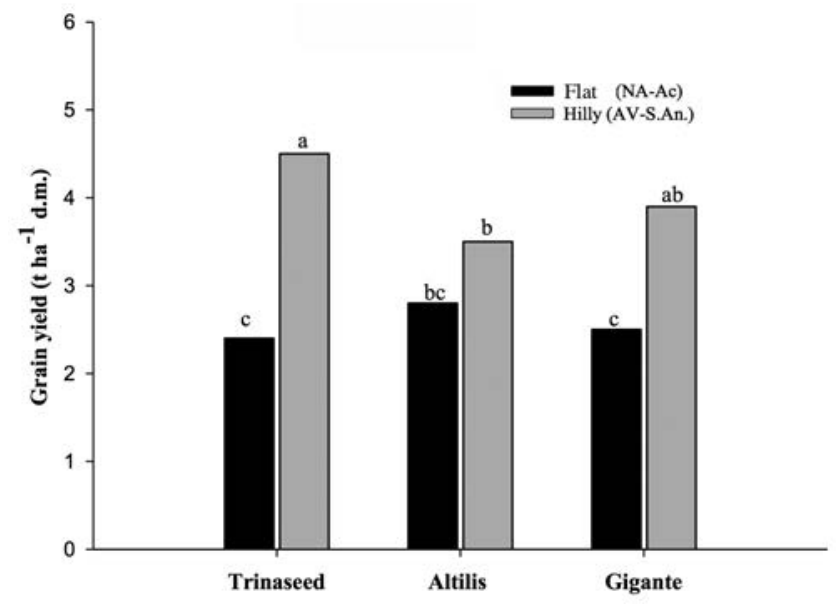

Figure 3. Interaction Locations $\times$ Cultivars: grain yield.

Table 3. Average values of main factors: yield parameters.

\begin{tabular}{|c|c|c|c|c|c|c|c|}
\hline & $\begin{array}{l}\text { Plant density } \\
\text { (num. } / \mathrm{m}^{2} \text { ) }\end{array}$ & $\begin{array}{l}\text { Total biomass } \\
\text { (t ha } \mathrm{a}^{-1} \text { d.m.) }\end{array}$ & $\begin{array}{l}\text { Crop residues } \\
\text { (t ha }{ }^{-1} \text { d.m.) }\end{array}$ & 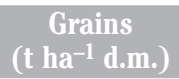 & HI (\%) & $\begin{array}{c}\mathrm{N} \\
\text { content }(\%)\end{array}$ & $\begin{array}{c}\mathrm{N} \\
\text { uptake }\left(\mathrm{kg} \mathrm{ha}^{-1}\right)\end{array}$ \\
\hline \multicolumn{8}{|l|}{ Year } \\
\hline 2013 & 3.9 & 24.5 & 17.8 & 4.4 & 18.0 & 0.35 & 87.0 \\
\hline 2014 & 2.4 & 20.3 & 13.2 & 3.6 & 17.7 & 0.35 & 67.2 \\
\hline 2015 & 1.8 & 13.4 & 8.0 & 1.8 & 13.4 & 0.36 & 52.9 \\
\hline \multicolumn{8}{|l|}{ Location } \\
\hline NA-Ac & 2.5 & 18.9 & 13.1 & 2.6 & 13.8 & 0.35 & 65.5 \\
\hline AV-S.An. & 2.8 & 20.0 & 12.9 & 4.0 & 20.0 & 0.35 & 72.5 \\
\hline \multicolumn{8}{|l|}{ Cultivar } \\
\hline Trinaseed & 2.6 & 19.1 & 12.3 & 3.5 & 18.3 & 0.35 & 69.5 \\
\hline Altilis & 2.6 & 19.3 & 13.0 & 3.2 & 16.6 & 0.35 & 66.6 \\
\hline Gigante & 2.8 & 19.9 & 13.7 & 3.2 & 16.1 & 0.36 & 71.0 \\
\hline \multicolumn{8}{|l|}{ Seed density } \\
\hline $4 / m^{2}$ & 2.4 & 19.2 & 13.0 & 3.2 & 16.7 & 0.35 & 69.0 \\
\hline $8 / m^{2}$ & 2.9 & 19.7 & 13.0 & 3.3 & 16.8 & 0.35 & 69.3 \\
\hline Average & 2.7 & 19.4 & 13.0 & 3.3 & 17.0 & 0.35 & 69.0 \\
\hline
\end{tabular}

HI, harvest index; N, nitrogen; NA-Ac, Acerra (NA); AV-S.An., S. Angelo (AV). 
The effects of the experimental factors on $\mathrm{N}$ content in whole plants of cardoon were not significant $(0.35 \%$ on the average, Tables 2 and 3). Therefore, $\mathrm{N}$ uptake (Table 4) reflected yield differences (Figure 4), with values from $30 \mathrm{~kg} \mathrm{ha}^{-1}$ to $150 \mathrm{~kg} \mathrm{ha}^{-1}$, in relation to the more or less unfavourable environmental conditions. In the two years in which plant growth and yield were affected by very unfavorable meteorological conditions, $\mathrm{N}$ uptake was very low (31-32 $\mathrm{kg} \mathrm{N} \mathrm{ha}^{-1}$ ), while in the normal years $\mathrm{N}$ uptake was $88 \mathrm{~kg} \mathrm{~N} \mathrm{ha}^{-1}$ on the average.
Table 4. Interaction Years $\times$ Locations: nitrogen uptake by cardoon plants.

\begin{tabular}{lccc} 
& \multicolumn{3}{c}{ N uptake $\left(\mathrm{kg} \mathrm{ha}^{-1}\right.$ tot) biomass } \\
& 2013 & 2014 & 2015 \\
NA-Ac & $90.1^{\mathrm{b}}$ & $31.6^{\mathrm{d}}$ & $74.8^{\mathrm{c}}$ \\
AV S.An. & $83.9^{\mathrm{b}}$ & $102.8^{\mathrm{a}}$ & $31.0^{\mathrm{d}}$ \\
\hline
\end{tabular}

NA-Ac, Acerra (NA); AV-S.An., S. Angelo (AV). a-dValues with different letters indicate significant differences per $\mathrm{P} \leq 0.05$.

Table 5. Correlation matrix between yields components.

\begin{tabular}{|c|c|c|c|c|c|c|c|}
\hline & Total biomass & Grain yield & Crop residues & Plant density & HI & N content & N uptake \\
\hline Total biomass & - & & & & & & \\
\hline Grain yield & $0.91^{*}$ & - & & & & & \\
\hline Crop residues & $0.96^{*}$ & $0.81^{*}$ & - & & & & \\
\hline Plant density & 0.23 & 0.38 & 0.32 & - & & & \\
\hline Harvest index & 0.63 & $0.87^{*}$ & 0.48 & 0.54 & - & & \\
\hline $\mathrm{N}$ content & -0.06 & 0.26 & -0.10 & 0.37 & 0.34 & - & \\
\hline N uptake & 0.53 & 0.24 & 0.51 & -0.35 & 0.03 & -0.75 & - \\
\hline
\end{tabular}

$\mathrm{HI}$, harvest index; $\mathrm{N}$, nitrogen. ${ }^{*} \mathrm{P} \leq 0.05$.

A

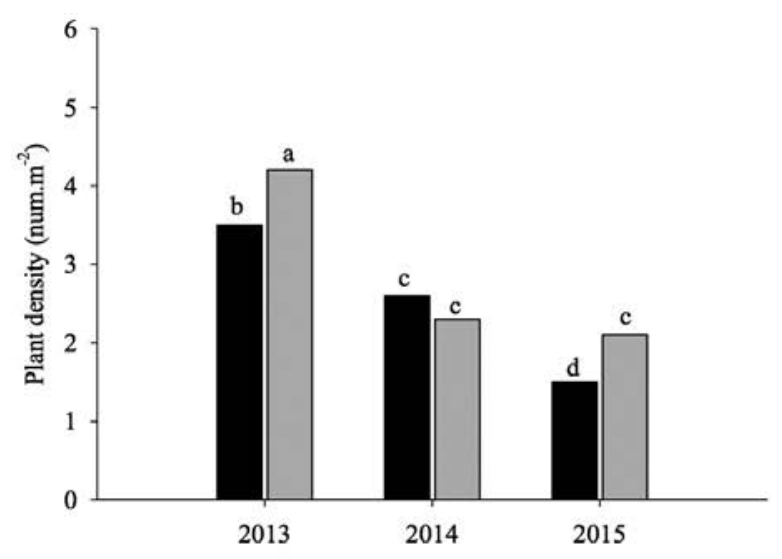

B

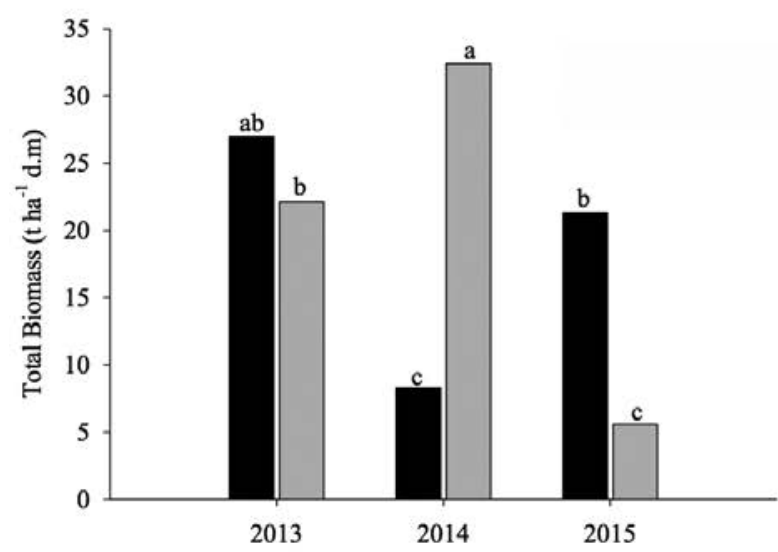

C

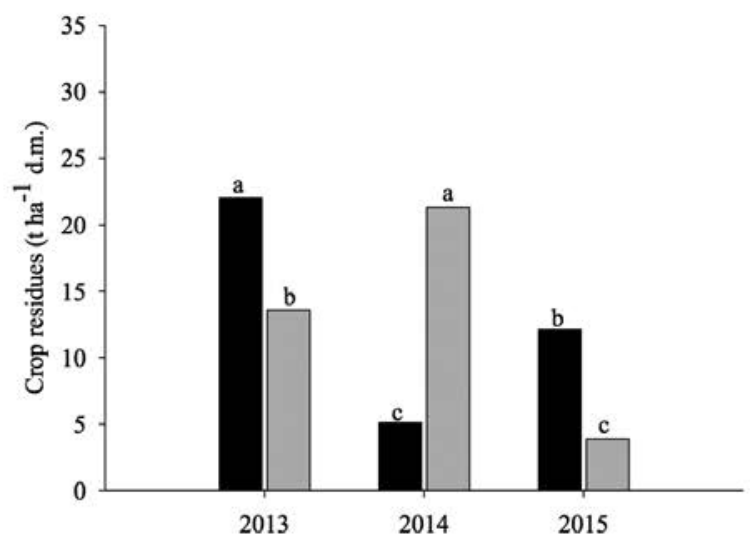

Flat (NA-Ac)

Hilly (AV-S.An.)

D

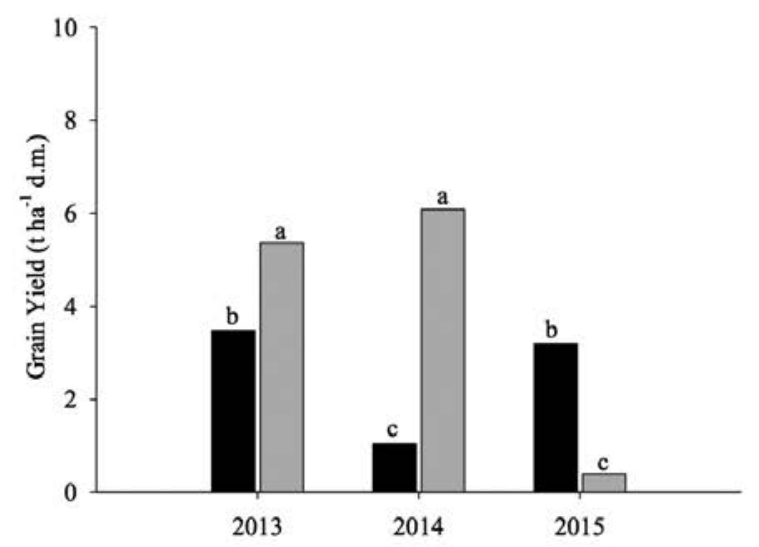

Figure 4. Interaction Years $\times$ Locations: A) plant density; B) total biomas; C) crop residues; D) grain yeld. Values with different letters indicate significant differences per $\mathrm{P} \leq 0.05$. 
Grain yield was correlated with total biomass yield and harvest index (Table 5) and not with plant density (number per $\mathrm{m}^{2}$ ), suggesting that grain yield is higher when environmental conditions allow a regular plant growth, irrespective of the number of plants.

\section{Soil carbon and nitrogen}

From the analysis of variance, no difference was significant as regards $\mathrm{C}$ and $\mathrm{N}$ into the soil.

$\mathrm{C}$ and $\mathrm{N}$ in the soil did not show clear trends (Figure 5), maybe for the short term of experimental period, since only long-term experiments allow measuring the impact of cropping systems on soil features. Anyway, in this three years period, the cardoon cropping system didn't show the positive effect on $\mathrm{C}$ storage into the soil that we could expect considering the absence of soil tillage. On the contrary other perennial crops, such as giant reed, showed a soil $\mathrm{C}$ increase that was considered an effect of the contribution of leaf fall, root exudates and turnover (Fagnano et al., 2015; Harper et al., 2012; Felten and Hemmerling, 2012; Chimento et al., 2016).

\section{Composition of lignocellulosic biomass}

As regards, biomass and grain composition measured in the last year, from the analysis of variance (Table 6) the interaction Locations $\times$ Cultivars was significant for cellulose and hemicellulose content (Table 7).

As regards main factors (Table 8), in the plain site there was higher hemicellulose content and a lower cellulose and protein content in residual biomass as compare to hilly site, while biomass and grain composition were not different between the cultivars.

A lower cellulose content and a higher hemicellulose content was measured in the flat site, as a response to the higher drought condition as also reported by Emerson et al. (2014) and Van der Weide et al. (2016); these authors related the decrease in cellulose content to the formation of osmolytes, aimed to the maintenance of osmotic equilibrium in the cell under dry conditions, at the expense of cellulose biosynthesis.

The increase in hemicelluloses content could be related to the exigence of plant to enable cell walls to uphold their structural rigidity without compromising plasticity (Le Gall et al., 2015;

Table 6. Analysis of variance of biomass composition: significance of main factors and interactions.

\begin{tabular}{lccccc} 
& & \multicolumn{2}{c}{ Crop residues } & & Grains \\
Hemicellulose & Cellulose & Lignin & Proteins & Proteins \\
Location & 0.01 & 0.01 & - & 0.01 & - \\
Cultivar & - & & - & - & - \\
\hline $\mathrm{L} \times \mathrm{C}$ & 0.01 & 0.05 & - & - & - \\
Density & - & - & - & - & - \\
$\mathrm{L} \times \mathrm{D}$ & - & - & - & - & - \\
$\mathrm{L} \times \mathrm{C}$ & - & - & - & - \\
$\mathrm{L} \times \mathrm{C} \times \mathrm{D}$ & - & - & -
\end{tabular}

Table 7. Interaction Locations $\times$ Cultivars: biomass composition.

\begin{tabular}{lcccccc} 
& & & & \multicolumn{2}{c}{ Cellulose } \\
& TRI & Gig & ALT & TRI & GIG & ALT \\
NA-Ac & $21.32^{\mathrm{a}}$ & $19.18^{\mathrm{b}}$ & $21.57^{\mathrm{a}}$ & $45.74^{\mathrm{c}}$ & $43.69^{\mathrm{d}}$ & $46.55^{\mathrm{c}}$ \\
AV-S.An & $12.55^{\mathrm{c}}$ & $11.11^{\mathrm{d}}$ & $11.19^{\mathrm{d}}$ & $50.00^{\mathrm{a}}$ & $46.60^{\mathrm{bc}}$ & $48.33^{\mathrm{ab}}$ \\
\hline
\end{tabular}

TRI, Trinaseed; GIG, Gigante; ALT, Altilis; NA-Ac, Acerra (NA); AV-S.An., S. Angelo (AV). a-dValues with different letters within columns indicate significant differences per P $\leq 0.05$.

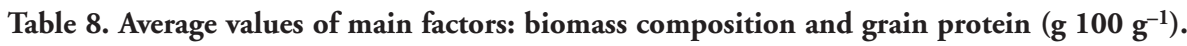

\begin{tabular}{|c|c|c|c|c|c|}
\hline & \multicolumn{4}{|c|}{ Crop residues } & \multirow{2}{*}{$\begin{array}{l}\text { Grains } \\
\text { Proteins }\end{array}$} \\
\hline & Hemicellulose & Cellulose & Lignin & Proteins & \\
\hline \multicolumn{6}{|l|}{ Location } \\
\hline NA-Ac & 20.7 & 45.3 & 12.9 & 2.2 & 15.0 \\
\hline AV-S.An. & 15.0 & 48.3 & 12.3 & 2.5 & 14.0 \\
\hline \multicolumn{6}{|l|}{ Cultivar } \\
\hline Trinaseed & 19.7 & 47.9 & 13.3 & 2.4 & 14.0 \\
\hline Altilis & 17.4 & 45.1 & 11.8 & 2.5 & 15.0 \\
\hline Gigante & 16.4 & 47.4 & 12.7 & 2.4 & 14.0 \\
\hline \multicolumn{6}{|l|}{ Seed density } \\
\hline $4 / \mathrm{m}^{2}$ & 18.2 & 46.7 & 12.8 & 2.2 & 14.8 \\
\hline $8 / \mathrm{m}^{2}$ & 17.4 & 47.3 & 12.4 & 2.3 & 14.0 \\
\hline Average & 17.8 & 46.8 & 12.6 & 2.3 & 14.4 \\
\hline
\end{tabular}

NA-Ac, Acerra (NA); AV-S.An., S. Angelo (AV). 
Tenhaken, 2015). These authors reported that hemicelluloses contribute to cell wall rigidity by reinforcing the cell wall matrix through cross-linking other fibres that could be more easily broken thus ensuring cell wall plasticity.

Lignin content was not different between sites and cultivars ( $12.6 \%$ on the average), confirming the findings of Van der Weide et al. (2016).

Protein and oil content of grains were not different between the factors analysed (14\% and $23 \%$ on the average, respectively).

Protein value was slightly lower than that reported by Genovese et al. (2016) (16\% in cv. Altilis), while it was much lower than those (21-22\%) reported by other studies made on different genotypes (Raccuia and Melilli, 2007). Oil content of seeds is similar to that reported by other Authors (Raccuia and Melilli, 2007).

\section{Conclusions}

Cardoon resulted a suitable crop for producing LC biomass and grains with low inputs in different Mediterranean croplands. Grain yield was higher in the hilly than in the flat site $(3.9 v s 2.7 \mathrm{t}$ $\mathrm{ha}^{-1}$ on average of the 3 -years experiment). On the contrary, LC biomass yield was more stable in relation to the environmental

A

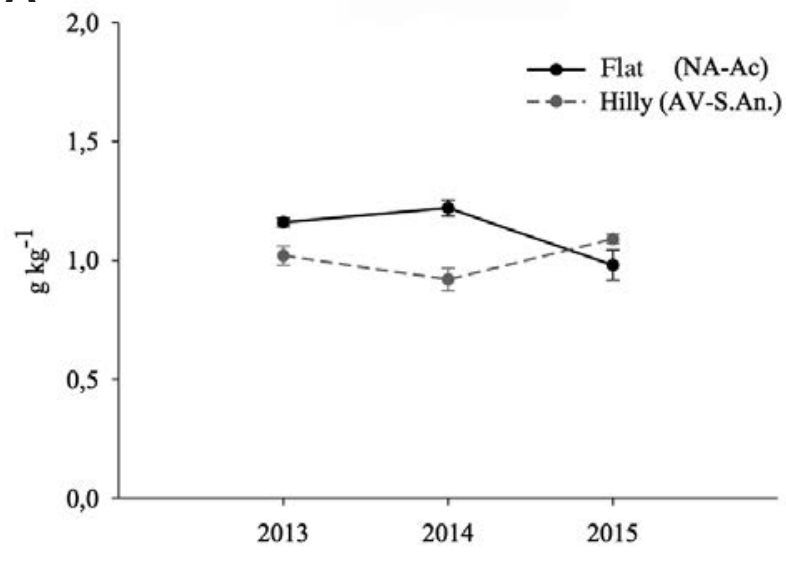

B

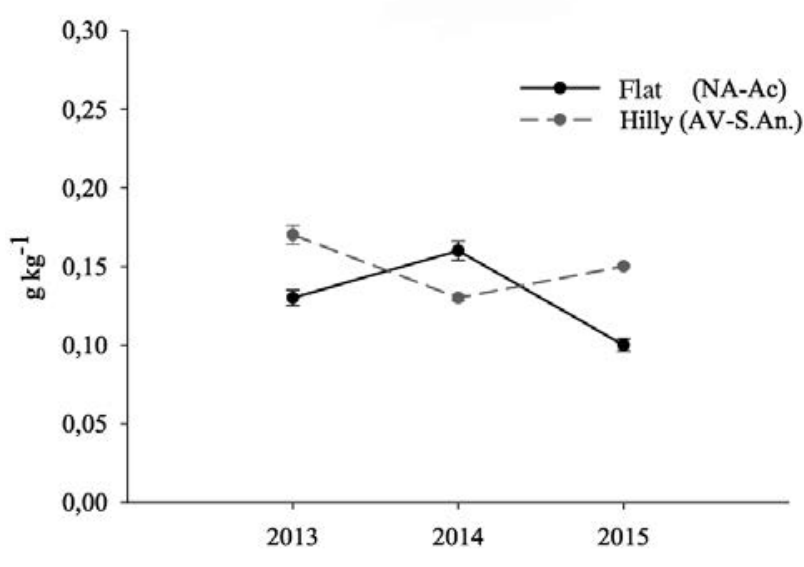

Figure 5. Trend of organic carbon (A) and nitrogen (B). conditions of the two sites $\left(20.1 \mathrm{t} \mathrm{ha}^{-1}\right.$ d.m. $v s 19.0 \mathrm{t} \mathrm{ha}^{-1}$ in hilly and flat sites, respectively). Biomass and grain composition were not very different. Only a decrease of cellulose and an increase of hemicellulose were measured in the flat site, maybe as a response of plants to the more drought conditions.

\section{References}

Antunes A, Amaral E, Belgacen MN, 2002. Cynara cardunculus L.: chemical composition and soda-anthraquinone cooking. Ind. Crop. Prod. 12:85-91.

Chimento C, Almagro M, Amaducci S, 2016. Carbon sequestration potential in perennial bioenergy crops: the importance of organic matter inputs and its physical protection GCB Bioenergy 8:111-21.

Cravero V, Martin E, Crippa I, López Anido F, García SM, Cointry E, 2012. Fresh biomass production and partitioning of aboveground growth in the three botanical varieties of Cynara cardunculus L. Ind. Crop Prod. 37:253-8.

Curt MD, Sánchez G, Fernández J, 2002. The potential of Cynara cardunculus L. for seed oil production in a perennial cultivation system. Biomass Bioen. 23:33-46.

Emerson R, Hoover A, Ray A, Lacey J, Cortez M, Payne C, Karlen D, Birrell S, Laird D, Kallenbach R, Egenolf J, Sousek M, Voigt T, 2014. Drought effects on composition and yield for corn stover, mixed grasses, and Miscanthus as bioenergy feedstocks. Biofuels 5:275-91.

Encinar JM, Gonzáles JF, Gonzáles J, 2002a. Steam gasification of Cynara cardunculus L. influence of variables. Fuel Process. Technol. 75:27-43.

Encinar JM, Gonzáles JF, Rodríguez JJ, Tejedor A, 2002b. Biodiesel fuels from vegetable oils: transesterification of Cynara cardunculus L. oils with ethanol. Energy Fuels 16:44350.

Encinar JM, González JF, Sabio E, Ramiro MJ, 1999. Preparation and properties of biodiesel from Cynara cardunculus L. oil. Ind. Eng. Chem. Res. 38:2927-31.

Fagnano M, Impagliazzo A, Mori M, Fiorentino N, 2015. Agronomic and environmental impacts of giant reed (Arundo donax L.): results from a long-term field experiment in hilly areas subject to soil erosion. Bio. Resear. 8:415-22.

Felten D, Emmerling C, 2012. Accumulation of Miscanthusderived carbon in soils in relation to soil depth and duration of land-use under commercial farming conditions. J. Plant Nutr. Soil Sci. 175:661-70.

Fernández J, Manzanares P, 1990. Production and utilization of Cynara cardunculus L. Biomass for energy, paper-pulp and food chemistry. In: G. Grassi, G. Gossi, G. dos Santos (eds.) Biomass for Energy and Industry. Elsevier Applied Science Publishing, New York, NY, USA, pp. 1189-984.

Fernández J, Hidalgo M, del Monte JP, Curt MD, 2005. Cynara cardunculus L. as a perennial crop for non-irrigated lands: yields and applications. Acta Hort. 681:109-13.

Fernandez J, Curt D, 2004. Low-costbiodiesel from Cynaraoil. In: 2nd World Conference and Exhibition on Biomass for Energy, Industry Climate Protection, Rome, Italy, May 10-14.

Fernández J, Curt MD, Aguado PL, 2006. Industrial applications of Cynara cardunculus L. for energy and other uses. Ind. Crop Prod. 24:222-9.

Fiorentino N, Fagnano M, Adamo P, Impagliazzo A, Mori M, Pepe O, Ventorino V, Zoina A, 2013. Assisted phytoextraction of 
heavy metals: compost and Trichoderma effects on giant reed uptake and soil quality. Ital. J. Agron. 8:244-54.

Fiorentino N, Ventorino V, Bertora C, Pepe O, Moschetti G, Grignani C, Fagnano M, 2016. Changes in soil mineral N content and abundances of bacterial communities involved in $\mathrm{N}$ reactions under laboratory conditions as predictors of soil $\mathrm{N}$ availability to maize under field conditions. Biol. Fert. Soil. 52:523-37.

Foti S, Mauromicale G, Raccuia SA, Fallico B, Fanella F, Maccarone E, 1999. Possible alternative utilization of Cynara spp. Part I. Biomass, grain yield and chemical composition of grain. Crop Prot. 10:219-28.

Gatto A, De Paola D, Bagnoli F, Vendramin GG, Sonnante G, 2013. Population structure of Cynara cardunculus complex and the origin of the conspecific crops artichoke and cardoon. Ann. Bot. 112:855-65.

Genovese C, Platania C, Venticinque M, Calderaro P, Argento S, Scandurra S, Raccuia SA, 2016. Evaluation of cardoon seeds presscake for animal feeding. Acta Hort. 1147:323-8.

Gherbin P, Monteleone M, Tarantino E, 2001. Five year evaluation on Cardoon (Cynara cardunculus L. var. altilis) biomass production in a Mediterranean environment. Ital. J. Agron. 5:11-9.

Goering, HK and Van Soest PJ, 1970. Forage fiber analysis (apparatus, reagents, procedures and some application). Agricultural Research Service, U.S. Department of Agriculture, Washington, DC, USA.

Gominho J, Fernandez J, Pereira H, 2001. Cynara cardunculus L.a new fibre crop for pulp and paper production. Ind. Crop Prod. 13:1-10.

Gonzáles JF, Gonzáles-García CM, Ramiro A, Gonzáles J, Sabio E, Gañan J, Rodriguez A, 2004a. Combustion optimization of biomass residues pellets for domestic heating with a mural boiler. Bioenergy 27:145-54.

Gonzáles J, Pérez F, Fernández J, Lezaun JA, Rodriguez D, Perea F, Romero C, Ochoa MJ, García M, 2004b. Study of Cynara cardunculus L: lignocellulosic biomass production in dry conditions Acta Hort. 660:221-7.

Hargreaves GH, Samani AK, 1985. Reference crop evapotranspiration from temperature. Appl. Eng. Agric. 1:96-9.

Harper RJ, Okom AEA, Stilwell AT, Tibbett M, Dean C, George SJ, Sochacki SJ, Mitchell CD, Mann SS, Dods K, 2012. Reforesting degraded agricultural landscapes with Eucalypts: effects on carbon storage and soil fertility after 26 years. Agric. Ecosyst. Environ. 163:3-13.

Ierna A, Mauro RP, Mauromicale G, 2012. Biomass, grain and energy yield in Cynara cardunculus L. as affected by fertilization, genotype and harvest time. Biomass Bioen. 36:404-10.

Kalamaras SD, Kotsopoulos TA, 2014. Anaerobic co-digestion of cattle manure and alternative crops for the substitution of maize in south Europe. Biores. Techn. 172:68-75.

Le Gall H, Philippe F, Domon JM, Gillet F, Pelloux J, Rayon C,
2015. Cell wall metabolism in response to abiotic stress. Plants 4:112-66.

Ma F, Hanna M, 1999. Biodiesel production: a review. Bioresource Technol. 70:1-15.

Maccarone E, Fallico B, Fanella F, Mauromicale G, Raccuia SA, Foti S, 1999. Possible alternative utilization of Cynara spp. II. Chemical characterization of their grain oil. Ind. Crop Prod. 10:229-37.

Ochoa MJ, Fandos A, 2004. Evaluation of vegetable cardoon (Cynara cardunculus L.) populations for biomass production under rainfed conditions Acta Hort. 660:235-9.

Piscioneri I, Sharma N, Baviello G, Orlandini S, 2000. Promising industrial energy crop, Cynara cardunculus: a potential source for biomass production and alternative energy. Energ. Convers. Manage. 41:1091-105.

Raccuia SA, Cavallaro V, Melilli MG, 2004. Intraspecific variability in Cynara cardunculus L. var. sylvestris Lam. Sicilian populations: seed germination under salt and moisture stresses. J. Arid Environ. 56:107-16.

Raccuia SA, Mainolfi A, Mandolino G and Melilli MG, 2004a. Genetic diversity in Cynara cardunculus revealed by AFLP markers: comparison between cultivars and wild types from Sicily. Plant Breeding 123:280-4.

Raccuia SA, Melilli MG, 2004. Cynara cardunculus L., a potential source of inulin in the Mediterranean environment: screening of genetic variability. Austral. J. Agricul. Res. 55:693-8.

Raccuia SA, Melilli MG, 2007. Biomass and grain oil yields in Cynara cardunculus L. genotypes grown in a Mediterranean environment. Field Crop Res. 101:187-97.

Raccuia SA, Melilli MG, 2010. Seasonal dynamics of biomass, inulin, and water-soluble sugars in roots of Cynara cardunculus L. Field Crop. Res. 116:147-53.

Raccuia SA, Piscioneri I, Sharma N, and Melilli MG, 2011. Genetic variability in Cynara cardunculus L. domestic and wild types for grain oil production and fatty acids composition. Biomass and Bioenergy 35:3167-73.

Sillitti C, Melilli MG, Padalino L, Bognanni R, Tringali S, Conte A, Raccuia SA, Del Nobile MA, 2016. Healthy pasta production using inulin from cardoon: First results of sensory evaluation. Acta Hort. 1147:407-12.

Tenhaken R, 2015. Cell wall remodeling under abiotic stress. Front. Plant Sci. 5:771.

Toscano V, Sollima L, Genovese C, Melilli MG, Raccuia SA, 2016. Pilot plant system for biodiesel and pellet production from Cardoon: technical and economic feasibility. Acta Hort. 1147:429-42.

Van Der Weijde T, Huxley LM, Hawkins S, Sembiring EH, Farrar K, Dolstra O, Visser RGF, Trindade LM, 2016. Impact of drought stress on growth and quality of miscanthus for biofuel production. GCB Bioener. 9:770-82. 